\title{
Distribution and lipid composition of early life stages of the cranchiid squid Galiteuthis glacialis (Chun) in the Weddell Sea, Antarctica
}

\author{
UWE PIATKOWSKI ${ }^{1}$ and WILHELM HAGEN² \\ ${ }^{2}$ Institut für Meereskunde, Universität Kiel, Düsternbrooker Weg 20, D-24105 Kiel, Germany \\ ${ }^{2}$ Institut für Polarökologie, Universität Kiel, Wischhofstr. 1-3, Gebäude 12, D-24148 Kiel, Germany
}

\begin{abstract}
The relatively small numbers of pelagic cephalopods caught in the RMT-8 samples (0-300 m) in February/March 1983 in the Weddell Sea were dominated by early life stages of the cranchiid squid Galiteuthis glacialis. A total of 48 specimens were caught with dorsal mantle length (ML) ranging from 4-36 mm. They occurred with a mean density of 0.15 ind. $x 1000 \mathrm{~m}^{-3}$ and were present in $38 \%$ of $33 \mathrm{RMT}-8$ samples. G. glacialis was the only cranchiid squid found in the Weddell Sea between $66^{\circ}$ and $74^{\circ} \mathrm{S}$. Its early life stages were concentrated in the layers below the summer thermocline $(>50 \mathrm{~m})$ and body sizes appeared to increase towards deeper water layers. For biochemical analyses, nine specimens of G. glacialis (ML 6-18 mm) were sampled in the eastern Weddell Sea between $185-520 \mathrm{~m}$ water depth in January/February 1985 . Total lipid contents ranged from $8 \%-11 \%$ dry weight (DW) with phospholipids being the main lipid component (43-56\% of total lipid). Storage lipids (triacylglycerols) made up $18-26 \%$ of total lipid. The relatively low lipid contents may reflect the early developmental stage of the specimens examined. The data presented give the first information on geographical and vertical distribution patterns of early life stages of $G$. glacialis in the high-Antarctic Weddell Sea, as well as on their lipid content and composition.
\end{abstract}

Received 5 July 1993, accepted 18 October 1993

Key words: Galiteuthis glacialis, squid, Antarctica, distribution, lipid composition, pelagic system

\section{Introduction}

Cranchiids are among the most numerous squids in the world oceans and may reach dorsal mantle lengths of up to $2.5 \mathrm{~m}$ (Klumov \& Yukhov 1975, Roper et al. 1985). All species are relatively transparent, with few chromatophores and a high degree of morphological diversity (Voss 1980). They are neutrally buoyant, since their acidified coelomic liquid, which forms a large portion of the total body weight, is of low density due to high concentrations of ammonium ions (Denton et al. 1969, Clarke et al. 1979). Cranchiids are preyed upon by a variety of marine top predators (Clarke 1977). In the Southern Ocean they are important prey organisms of birds, seals and whales (Clarke 1980, Cooper et al.1992, Rodhouse et al. 1992), which together are estimated to consume about 34 million tonnes of cephalopods each year (Clarke 1983).

Galiteuthis glacialis is a cranchiid squid of the subfamily Taoninae (Voss 1980). The species is endemic in the Southern Ocean and occurs only sporadically north of the Antarctic Polar Front (APF) (Filippova \& Yukvov 1979, Roper et al. 1985, Nesis 1987, Kubodera 1989). Adetailed study of the systematics and morphology of $G$. glacialis was provided by McSweeny (1978). G. glacialis is a moderately large species that attains a maximum mantle size of $500 \mathrm{~mm}$ (McSweeny 1978). It can easily be distinguished from the one other described cranchiid speciesoccurring south of the APF, Mesonychoteuthishamiltoni, by its characteristic arrangements of tubercles at the nuchal and funnel-mantle fusion cartilages (Rodhouse \& Clarke 1985, Roper et al. 1985, Voss et al. 1992).

Large specimens of $G$. glacialis (> $250 \mathrm{~mm}$ dorsal mantle length) live below $700 \mathrm{~m}$ in meso- and bathypelagic layers of the oceanic Antarctic (Rodhouse \& Clarke 1986). The early life stages concentrate between about $300-1000 \mathrm{~m}$, but may also occur in the top $300 \mathrm{~m}$ (Rodhouse \& Clarke 1986). During the ANT I Expedition of RV Polarstern in austral summer 1983, specimens of $G$. glacialis were found quite frequently in RMT-8 samples and they were a typical component in the oceanic macrozooplankton community of the Weddell Sea as described by Boysen-Ennen \& Piatkowski (1988).

Our knowledge on high-Antarctic macroplankton communities has grown considerably during the last years (Boysen-Ennen \& Piatkowski 1988, Lancraft etal. 1989, 1991). However, data on the distribution patterns of early life stages of Antarctic squids still remain scarce due to inadequacy of sampling techniques, avoidance and patchiness (Wormuth \& Roper 1983). Apart from the collections during the RRS Discovery cruise 100 in the $15-30^{\circ}$ Esector (Rodhouse \& Clarke 1985,1986 , Rodhouse 1988), Japanese samples from the Indian Ocean sector (Kubodera 1989) and Russian samples from Prydz Bay (Filippova \& Pachomov 1990), no data are available on the distribution of early life stages of squids in the Southern Ocean. There are only two reports on the cephalopod fauna of the 


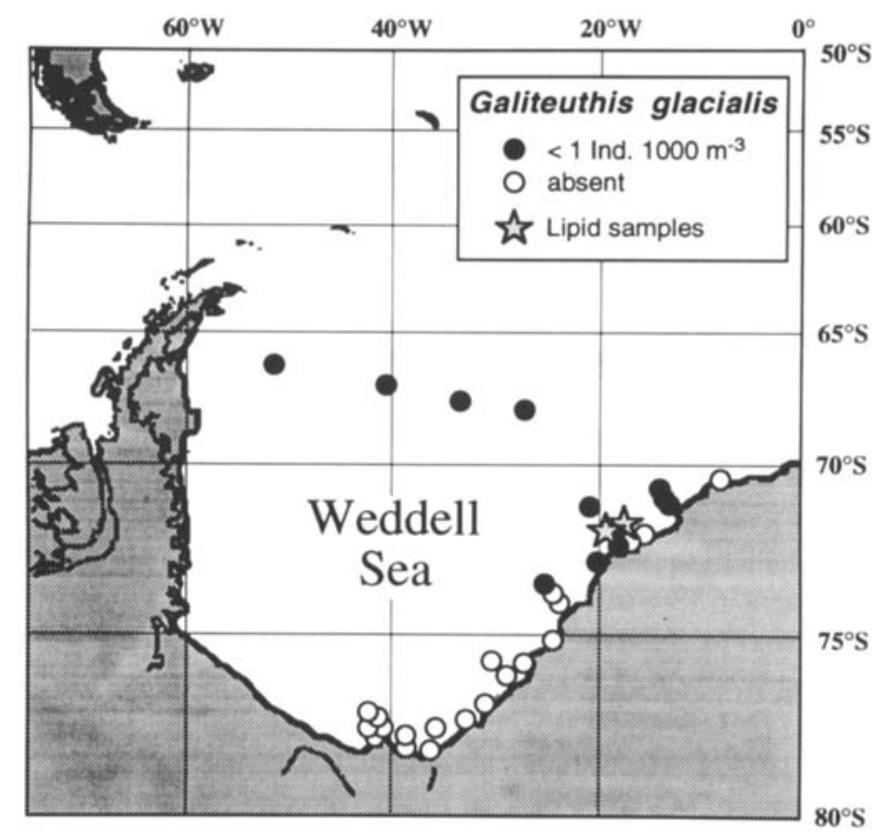

Fig. 1. Galiteuthis glacialis. RMT stations for distributional and biochemical investigations. Geographical distribution and relative abundance of early life stages during February/March 1983.

Weddell Sea (Piatkowski 1987, Piatkowski et al. 1990).

The aim of the present study is to illustrate the distribution of young $G$. glacialis during an austral summer macrozooplankton survey in the Weddell Sea, and to present the first data on the lipid content and composition of this cranchiid squid. The latter provides new information on the energetics of this highAntarctic squid.

\section{Material and methods}

Macrozooplankton samples were collected in February/March 1983 during the ANT I Expedition of RV Polarstern using an opening/closing rectangular midwater trawl (RMT-1+8) based on the design principle described by Baker et al. (1973). The trawl consists of two net systems, which fish simultaneously with different mesh sizes (RMT-1: $320 \mu \mathrm{m}$; RMT-8: $4500 \mu \mathrm{m}$ ) and mouth openings (RMT-1: $1 \mathrm{~m}^{2}$; RMT-8: $8 \mathrm{~m}^{2}$ ). Our RMTwas equipped with three pairs of nets, which were opened and closed sequentially by hydroacoustic transmission. Standard oblique hauls were made in the depth strata $300-200 \mathrm{~m}$, $200-50 \mathrm{~m}$ and $50-0 \mathrm{~m}$. Only RMT -8 samples were considered in the present study, and relative abundance $\left(n \times 1000 \mathrm{~m}^{-3}\right)$ was calculated for the entire $0-300 \mathrm{~m}$ layer. Filtered water volumes were calculated considering net speed, net angle and flow data according to Roe et al. (1980). A map of the sampling locations is given in Fig. 1. Specimens of $G$. glacialis were sorted from the RMT-8 samples directly after capture. Dorsal mantle length (ML) of each specimen was measured to the nearest $\mathrm{mm}$. Samples were then fixed in $4 \%$ formalin/seawater solution.

For dry weight (DW) and lipid analyses nine specimens of

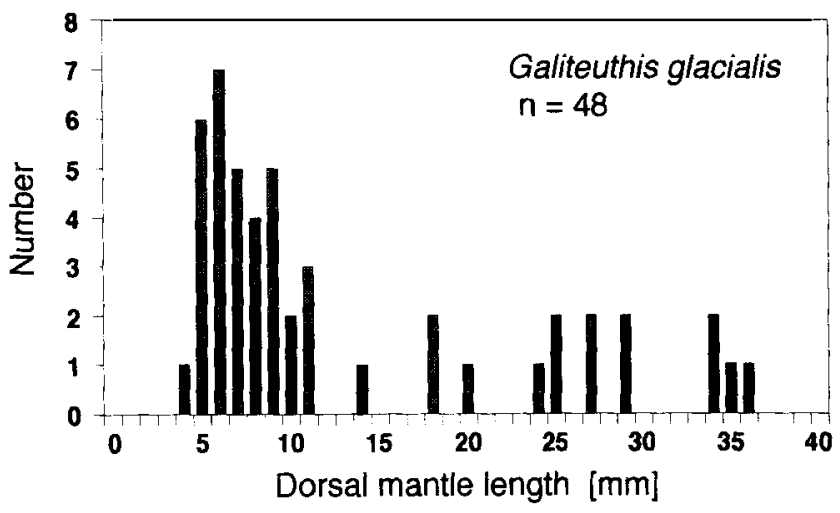

Fig. 2. Galiteuthis glacialis. Size composition of catch.

early G. glacialis were collected from two RMT $-1+8$ samples during the ANT III/3 Expedition of RV Polarstern in January/February 1985. The animals were collected in the Vestkapp region of the eastern Weddell Sea (Fig. 1). Six specimens were caught on 29 January 1985 in $300-185 \mathrm{~m}$ and threespecimenson 17 February 1985 in $520-200 \mathrm{~m}$. Immediately after sampling, live G. glacialis were sorted from the RMT-8 catches in a cooling container at $4^{\circ} \mathrm{C}$. After measuring their size, the specimens were stored in glass vials under nitrogen at $-80^{\circ} \mathrm{C}$. In the home laboratory, wet weight (WW) and dry weight (DW) (after freeze-drying for $48 \mathrm{~h}$ ) were determined. Total lipid content was measured gravimetrically after Folch et al.(1957). The lipid class composition was analysed according to Fraser et al. (1985) by thin-layer chromatography-flame ionization detection with an IATROSCAN (Ackman 1981). Standard mixtures were prepared for calibration that approximated the lipid class composition of the analysed samples. For detailed descriptions of the procedures see Hagen (1988).

\section{Results}

\section{Distribution and size structure}

Geographical distribution and relative abundance $\left(n \times 1000 \mathrm{~m}^{-3}\right)$ of G. glacialis in the Weddell Sea are shown in Fig. 1. The squids concentrated in the oceanic regions of the northern and eastern parts of the investigated area, but they were absent in the southern Weddell Sea. The southernmost record was at $74^{\circ} 08.4^{\prime} \mathrm{S}, 24^{\circ} 24.5^{\prime} \mathrm{W}$ (Fig. 1).

A total of 48 specimens of $G$. glacialis were collected. Nine specimens (19\%) were sampled in the 0-50 $\mathrm{m}$ layer, $22(46 \%)$ in the 50-200 m layer and $17(35 \%)$ in the $200-300 \mathrm{~m}$ layer. This vertical distribution pattern emphasizes the preference of $G$. glacialis to remain below the warmer and less saline upper surface layer of the summer Weddell Sea.

Due to the net used, the samples only consisted of early life stages of G. glacialis with ML 4-36 mm (Fig. 2). The vertical size structure of $G$. glacialis is shown in Fig. 3. The largest specimens were caught in the $50-200 \mathrm{~m}$ and $200-300 \mathrm{~m}$ layers. Single animals in the upper surface layer $(0-50 \mathrm{~m})$ attained 
maximum ML of $25 \mathrm{~mm}$. The vertical size distribution patterns indicate the typical developmental descent of cranchiid squids with increasing body size towards deeper water layers.

\section{Lipid data}

Two samples of G. glacialis were analysed. Six specimens were collected at the end of January 1985 between 185 and $300 \mathrm{~m}$ depth and three specimens in mid-February 1985 in $200-520 \mathrm{~m}$ depth in the Vestkapp region(Fig. 1). The ML of the first group was $12-18 \mathrm{~mm}$ and of the second group 6-11 $\mathrm{mm}$. Their mean dry weight(DW) was $24 \mathrm{mg}$ and $14 \mathrm{mg}$, respectively; mean wet weight(WW) was $404 \mathrm{mg}$ and $196 \mathrm{mg}$. Mean total lipid content was $7.5 \% \mathrm{DW}(0.45 \% \mathrm{WW})$ at the end of January and $11.1 \%$ DW $(0.77 \% \mathrm{WW})$ in mid-February. The lipidclass composition of both samples was quite similar. Due to the rather low lipid contents polar lipids dominated (56\% and $43 \%$ of total lipid), mainly phosphatidylcholine (33\% and $24 \%$ ) and phosphatidylethanolamine (20\% and $17 \%$ ). Sterols comprised $14 \%$ and $11 \%$. Major neutral lipid compounds were triacylglycerols (18\% and $26 \%$ ) and wax esters/sterol esters ( $8 \%$ and $17 \%$ ). Low amounts of free fatty acids ( $4 \%$ ) indicate that the samples did not suffer from artifacts such as autolysis (Table I).

\section{Discussion}

\section{Distribution patterns}

Despite the small data set, these results present the first information on the distribution patterns of the Antarctic squid $G$. glacialis in the Weddell Sea. The species was mainly concentrated in the open ocean as well as along the steep continental slope of the eastern Weddell Sea. G. glacialis did not occur in shallow shelf regions or the southern Weddell Sea, but preferred the oceanic regions, which is typical for all cranchiid squids (Voss 1980, Nesis 1987).

Its vertical distribution pattern indicates a preference to remain below the summer upper surface layer. The top layer $(0-50 \mathrm{~m})$ was mostly inhabited by small early life stages of G. glacialis (ML 5-9 mm), whereas larger specimens ( $>30 \mathrm{~mm} \mathrm{ML}$ ) occurred only below the summer thermocline $(>50 \mathrm{~m})$. This distribution pattern reflects the developmental

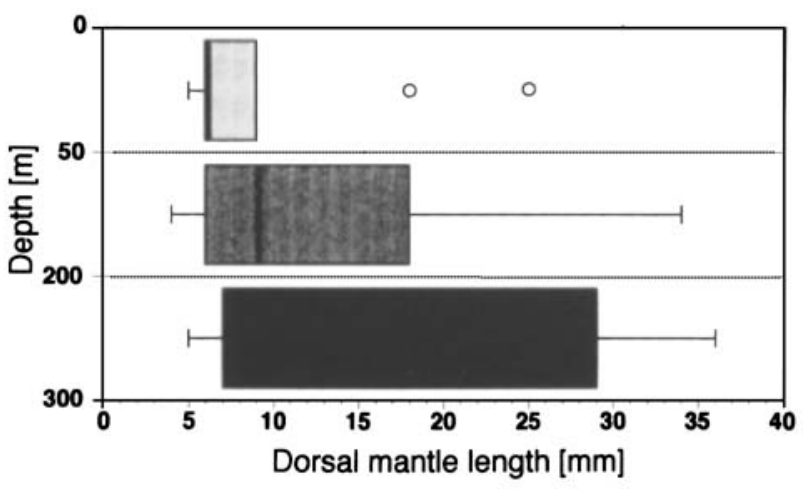

Fig. 3. Galiteuthis glacialis. Vertical size distribution.

descent of $G$. glacialis with increasing body size towards deeper layers, a phenomenon characteristic for cranchiid squids and well documented for G. glacialis (McSweeny 1978, Rodhouse \& Clarke 1986).

However, large numbers of cephalopod beaks found in the stomachs of emperor penguins and Weddell seals in the southeastern Weddell Sea (Klages 1989, Plötz et al. 1991) suggest reasonable concentrations of other squids in coastal waters of the Antarctic continent. G. glacialis is not a common prey organism of Weddell Sea top predators (Klages 1989, Plötz et al. 1991), although its early life stages have regularly been found in macrozooplankton and micronekton samples from the Weddell Sea (Boysen-Ennen \& Piatkowski 1988, Piatkowski et al. 1990). This species is probably less attractive to seals and penguins due to its jelly-like appearance which may indicate a prey of low energy content. The more fleshy Antarctic squids Alluroteuthis antarcticus and Psychroteuthis glacialis are the principal cephalopod diet of top Weddell Sea predators (Klages 1989, Plötz et al. 1991), but, no data on their energy content are available. Another explanation why $G$. glacialis is missing in predator stomachs could be that the (possibly more attractive) adults of $G$. glacialis inhabit the deeper mesopelagic and bathypelagic layers ( $>700 \mathrm{~m}$ ) of the open ocean and the continental slope (Rodhouse \& Clarke 1986). These regions may be too remote from the common feeding grounds of emperor penguins and Weddell seals.

Our data support the latter assumption, as most of the

Table I. Galiteuthis glacialis. Sampling data, dorsal mantle length (ML), wet weight (WW), dry weight (DW), lipid content and lipid composition. Lipid class composition in percent of total lipid (PC: phosphatidylcholine, PE: phosphatidylethanolamine, PS: phosphatidylserine, phosphatidylinositol, SM: sphingomyeline, LPC: lysophosphatidylcholine, TAG: triacylglycerols, WE: wax esters, SE: sterol esters, STER: sterols, FFA: free fatty acids, DAG: diacylglycerols).

\begin{tabular}{|c|c|c|c|c|c|c|c|c|c|}
\hline $\begin{array}{l}\text { Sampling } \\
\text { Date } \\
\text { D/M/Y }\end{array}$ & $\begin{array}{l}\text { Haul } \\
\text { depth } \\
\text { (m) }\end{array}$ & $\begin{array}{c}\text { Number of } \\
\text { specimens } \\
n\end{array}$ & $\begin{array}{c}\text { Length } \\
\text { ML } \\
(\mathrm{mm})\end{array}$ & $\begin{array}{c}\text { Mean } \\
\text { WW } \\
(\mathrm{mg})\end{array}$ & $\begin{array}{c}\text { Mean } \\
\text { DW } \\
(\mathrm{mg})\end{array}$ & $\begin{array}{c}\text { Mean } \\
\text { lipid } \\
(\mathrm{mg})\end{array}$ & $\begin{array}{c}\text { Total } \\
\text { lipid } \\
\% W W\end{array}$ & $\begin{array}{l}\text { Total } \\
\text { lipid } \\
\text { \%DW }\end{array}$ & \\
\hline \multirow[t]{2}{*}{$17 / 02 / 85$} & $520-200$ & 3 & $6-11$ & 195.8 & 13.6 & 1.5 & 0.77 & 11.1 & \\
\hline & $\mathrm{PC}$ & $\mathrm{PE}$ & $P S+P I$ & $\mathrm{SM}+\mathrm{LPC}$ & TAG & $\mathrm{WE}+\mathrm{SE}$ & STER & FFA & DAG \\
\hline
\end{tabular}


specimens were caught in surface waters of the more oceanic part of the Weddell Sea or above the steep continental slope (see Fig. 1). It should be noted, however, that digested parts and a gladius of a larger $G$. glacialis specimen (gladius length $150 \mathrm{~mm}$ ) have been found in the stomach of the demersal icefish Chionobathyscus dewitti. This fish was caught in a bottom trawl at c. $2000 \mathrm{~m}$ on the eastern slope of the Weddell Sea (Kock \& Piatkowski unpublished data). This finding, and the increasing body size of $G$. glacialis towards greater depths, demonstrate that larger G. glacialis are a potential prey item for predators cooccurring in deeper water layers.

\section{Lipid data}

In 1982 Croxall \& Prince noted the lack of data on the chemical composition and calorific content of Antarctic squid, although this group forms a principal part of the diet of marine mammals and birds in the Southern Ocean, particularly in the South Georgian area. They suggested that this information should be "rapidly obtained" for a better understanding of the energy flux through the Antarctic food web. However, more than a decade latercomparable data on the biochemicalcomposition of Antarctic cephalopods are still lacking for adults as well as for early developmental stages. This is not surprising, since young cephalopods have not been an abundant group in plankton samples during recent Antarctic expeditions and larger specimens, with theirhighswimming speed, successfully manage to avoid the currently used nets and trawls. Furthermore, chemical and calorific analyses of marine Antarctic invertebrates are generally rather sparse (Clarke 1984, Hagen 1988, Clarke et al. 1992).

Low lipid contents $(0.5-0.8 \%$ WW; $8-11 \%$ DW), large phospholipid and sterol fractions and small amounts of reserve lipids, mainly triacyglycerols, seem to reflect the early developmentalstage of the investigated specimens of $G$. glacialis. These compositions are likely to differ considerably from those of adult specimens which can be expected to accumulate larger energy reserves than the rapidly developing early stages, where most of the energy is channeled towards protein growth. For instance, total lipid contents of adult Northern shortfin squid Illex illecebrosus from the Northwest Atlantic (Nova Scotia) were much higher at $5.6 \% \mathrm{WW}$. The mantle contained only $1.5 \% \mathrm{WW}$ lipid, whereas the digestive gland (liver) had a very high lipid content of $11.6 \% \mathrm{WW}$ (Nash etal. 1978). The authors also identified triacylglycerols as the major deposited lipid. Extremely highlipid contents $(20.5-60.5 \% \mathrm{WW})$ were measured for the digestive gland of the gonatid squid Berryteuthismagister from the Northwest Pacific Ocean and this needs further investigation (Hayashi \& Yamamoto 1987). Low lipid contents are typical for ommastrephid squids, which must actively swim to avoid sinking (Clarke et al. 1979). They tanged between $0.4-1.5 \% \mathrm{WW}$ in the mantle tissues of four ommastrephid squids, Illexillecebrosus, Nototodarussloaniisloanii, Todarodes pacificus and Ommastrephes bartramii (Hayashi \& Takagi 1979). Lipid contents were slightly higher in the mantles of the
California market squidLoligoopalescens and the ommastrephid Argentine shortfin squid Illex argentinus with $2.7 \%$ and $2.0 \%$ WW, respectively (Suyama \& Kobayashi 1980). Maximum lipid contents in squid mantle have recently been reported for the subantarctic onychoteuthid squid Moroteuthis ingens with 3.1\% WW (Cherel \& Ridoux 1992). Croxall \& Prince (1982) compiled data on the chemical composition and calorific content of 16 cephalopod species, of which 10 were squids. Although none of the squids were from Antarctic waters, the authors noted the lower calorific content of this group as compared to krill and fish, and explained this by their low lipid contents (mean of $0.9 \% \mathrm{WW}$ ).

Many oceanic cephalopods and all cranchiid squids regulate their buoyancy by means of a voluminous coelomic fluid with high concentrations of ammonium ions (Denton et al. 1969, Clarke et al. 1979). G. glacialis does not seem to depend on lipids as buoyancy aids, which is confirmed by its relatively low lipid content. In contrast, the gonate squid Gonatus fabricii maintain their buoyancy by accumulating larger lipid deposits, especially in the digestive gland (Clarke et al. 1979).

In summary, as Croxall \& Prince (1982) emphasized more than ten years ago, we urgently need more data on the fine-scale distribution and chemical composition of Southern Ocean squids, together with detailed information on sexual maturity and feeding conditions, supported by sound taxonomy. This knowledge will contribute to a better understanding of the biology of Antarctic squid and their role in the pelagic system of the Southern Ocean.

\section{Acknowledgements}

We would like to thank our colleagues during the expeditions, and the officers and crew of RV Polarstern for their skillful support during station work. We also thank Werner Dzomla and Christopher Zimmermann, Institut für Polarökologie, for their help in preparing the graphs and the reviewers Prof. A. Clarke and Prof. N. Voss for their helpful criticisms.

Financial support for presenting this research at the Southern Ocean Cephalopods Symposium in Cambridge was obtained from the British-German Academic Research Collaboration Programme (ARC) of the British Council and the Deutsches Akademisches Austanschdienst (DAAD, Grant No. AT313ARC-VI-92/65).

\section{References}

ACKmAN, R.G. 1981. Flame ionization detection applied to thin-layer chromatography on coated quartz rods. Methods in Enzymology, 72, 205-252.

BAKER, A. DE C., ClaRKE, M.R. \& HaRRIS, M.J. 1973. The N.I.O. Combination Net (RMT-1+8) and further developments of rectangular midwater trawls. Journal of the Marine Biological Association of the UK, 53, 167-184.

BOYSEN-ENNEN, E. \& PiATKowsKI, U. 1988. Meso- and macrozooplankton communities in the Weddell Sea, Antarctica. Polar Biology, 9, 17-35.

CHEREL, Y. \& Ridoux, V. 1992. Prey species and nutritive value of food fed during summer toking PenguinAptenodytes patagonica chicks at Possession Island, Crozet Archipelago. Ibis, 134, 118-127. 
ClaRKE, A. 1984. The lipid content of some Antarctic mactozooplankton. British Antarctic Survey Bulletin, No. 63, 55-70.

Clarke, A., Holmes, L.J. \& Gore, D.J. 1992. Proximate and elemental composition of gelatinous zooplankton from the Southem Ocean. Journal of Experimental Marine Biology and Ecology, 155, 55-68.

ClARKE, M.R. 1977. Beaks, nets and numbers. Symposia of the Zoological Society of London, 38, 89-126.

ClaRKE, M.R. 1980. Cephalopoda in the diet of sperm whales of the Southern Ocean hemisphere and their bearing on sperm whale biology. Discovery Reports, 37, 1-324.

CLARKE, M.R. 1983. Cephalopod biomass - estimation from predation. Memoirs of the National Museum of Victoria, 44, 85-107.

Clarke, M.R, Denton, E.J. \& Gilpin-Brown, J.B. 1979. On the use of ammonium for buoyancy in squids. Journal of the Marine Biological Association of the United Kingdom, 59, 259-276.

COOPER, J., HENley, S.R. \& KLAGES, N.T.W. 1992. The diet of the wandering albatross Diomedea exulans at subantarctic Marion Island. Polar Biology, $12,477-484$.

Croxall, J.P. \& Prince, P.A. 1982. Calorific content of squid (Mollusca: Cephalopoda). British Antarctic Survey Bulletin, No. 55, $27-31$.

Denton, E.J., Gilpin-Brown, J.B. \& Shaw, T.I. 1969. A buoyancy mechanism found in cranchid squid. Proceedings of the Royal Society of London, B174, 271-279.

FIUPPoVa, J.A., YUKHov, V.L. 1979. [Species composition and distribution of cephalopods in the meso- and bathypelagic layers of the Antarctic waters.] Antarktika Doklady Kommission, 18, 175-187. [In Russian.]

FiLuppova, J.A. \& PACHOMOV, E.A. 1990. [Larvae and juvenile squids in the plankton community of the Prydz Bay region.] In V. All-Union Conference on Commercial Invertebrates (Minsk/Naroch, 9-13 October 1990). Abstracts of Communications, Moscow, p. 96-97. [In Russian.]

Folch, J., Lees, M. \& Sloane-Stanley, G.H. 1957. A simple method for the isolation and purification of total lipids from animal tissues. Journal of Biological Chemistry, 226, 496-509.

FRASER, A.J., TOCHER, D.R. \& SARGENT, J.R. 1985. Thin-layer chromatography - flame ionization detection and the quantitation of marine neutral lipids and phospholipids. Journal of Experimental Marine Biology and Ecology, 88, 91-100.

HAGEN, W. 1988. [On the significance of lipids in Antarctic zooplankton.] Berichte zur Polarforschung, 49, 1-129. [in German; English version (1989): Canadian Translation of Fisheries and Aquatic Sciences, No. $5458,1-149$.]

HAYASH, K. \& TAKAGI, T. 1979. Browning of dried-seasoned squid product. 1. On the chemical constituents for amino acids and fatty acids of squid mantles. Bulletin of the Faculty of Fisheries Hokkaido University, 30, 288-293.

HAYASH, X. \& YAMAMOTO, S. 1987. Distribution of diacyl glyceryl ethers in the different tissues and stomach contents of gonatid squid Berryteuthis magister. Bulletin of the Japanese Society of Scientific Fisheries, 53, 1057-1063.

KLages, N.T.W, 1989. Food and feeding ecology of emperor penguins in the eastern Weddell Sea. Polar Biology, 9, 385-390.

KLuMOV, S.K. \& YUKHOV, V.L. 1975. [Mesonychoteuthis hamiltoni Robson, 1925 (Cephalopoda, Oegopsida).] Antarktika Doklady Kommission, 14, 159-189. [In Russian.]

KUBODERA, T. 1989. Young squids collected with 10-foot IKPT net during the JARE-28 cruise, 1987. Proceedings of the NIPR Symposium on Polar Biology, 2, 71-77.
LANCraft, T.M., Torres, J.J. \& Hopkins, T.L. 1989. Micronekton and macrozooplankton in the openwatersnear Antarcticice edgezones (AMERIEZ 1983 and 1986). Polar Biology, 9, 225-233.

Lancraft, T.M., Hopkins, T.L., Torres, J.J. \& Donnelly, J. 1991. Oceanic micronektonic/macrozooplanktonic community structure and feeding in ice covered Antarctic waters during the winter (AMERIEZ 1988). Polar Biology, 11, 157-167.

MCSWEENY, E.S. 1978. Systematics and morphology of the Antarctic cranchiid squid Galiteuthis glacialis (Chun). In PAwson, D.L. ed. Biology of the Antarctic Seas VII. Antarctic Research Series, 27, 1-39.

NASH, D.M., EATON, C.A. \& CREWE, N.F. 1978. Lipid classes and fatty acid composition of squid(Illexillecebrosus). TechnicalReports of the Fisheries and Marine Service of Canada, No. 833, 8 pp.

NEsis, K.N. 1987. Cephalopods of the world. Neptune City, NJ: T.F.H. Publications, $351 \mathrm{pp}$.

PlatKowSK, U.1987. [Zoogeographical investigations and community analyses on Antarctic macroplankton.] Berichte zur Polarforschung, 34, 1-150. [In German]

Platkowsk, U., White, M. \& Dimmer, W. 1990. Micronekton of the Weddell Sea: Distribution and abundance. In ARNTz, W., ERNST, W. \& HEMPEL, I. eds. The ExpeditionANTARKTIS VII/4 (EPOSleg 3) and VII/5 of RV "Polarstem" in 1989. Berichte zur Polarforschung, 68, 73-81.

PLöTZ, J.,EKaU, W. \& Rejnders, P.J.H. 1991. Diet of Weddell seaisL Leptonychotes weddellii at Vestkapp, eastern Weddell Sea (Antarctica), in relation to local food supply. Marine Mammal Science, 7, 136-144.

RodHouse, P.G. 1988. Distribution of the neoteuthid squid Alluroteuthis antarcticus Odhner in the Atlantic sector of the Southern Ocean.Malacologia, 29, 267-274.

RoDHouse, P.G. \& Clarke, M.R. 1985. Growth and distribution of young Mesonychoteuthis hamiltoni Robson(Mollusca: Cephalopoda): an Antarctic squid. Vie et Milieu, 35, 223-230.

RODHOUSE, P.G. \& CLARKE, M.R. 1986. Distribution of the early-life phase of the Antarctic squid Galiteuthis glacialis in relation to the hydrology of the Southern Ocean in the sector $15^{\circ}$ to $30^{\circ}$ E. Marine Biology, 91, 353-357.

Rodhouse, P.G., Arnbom, T.R., Fedak, M.A., Yeatman, J. \& Murray, A.W.A. 1992. Cephalopod prey of the southern elephant seal, Mirounga leonina $\mathrm{L}$ Canadian Journal of Zoology, 70, 1007-1015.

ROE, H.S.J., Baker, A. de C., CARSon, R.M., Wild, R. \& Shale, D.M. 1980. Behaviour of the Institute of Oceanographic Science's Rectangular Midwater Trawls: Theoretical aspects and experimental observations. Marine Biology, $56,247-259$.

Roper, C.F.E., SWEenEY, M.J. \& ClarkE, M.R. 1985. Cephalopods. In Fischer, W. \& HuREAU, J.C. eds. FAO species identification sheets for fishery purposes. Southern Ocean (Fishing areas 48, 58 and 88) (CCAMLR Convention area). Rome: FAO, Vol. 1, 117-205.

SUYAMA, M. \& KOBAYASH, H. 1980. Free amino acids and quaternary ammonium bases in mantle muscles of squid. Bulletin of the Japanese Society of Scientific Fisheries, 46, 1261-1264.

Voss, N.A. 1980. A revision of the Cranchiidae (Cephalopoda; Oegopsida). Bulletin of Marine Science, 30, 365-412.

Voss, N.A., STEPHEN, S.J. \& Dong, Z. 1992. Family Cranchiidae Prosch, 1849. In SWEeney, M.J., Roper, C.F.E., MANGold, K.M. Clarke, M.R. \& BoletzKY, S. von eds. "Larval" and juvenile cephalopods: a manual for their identification. Smithsonian Contributions to Zoology, No. 513, 187-210.

WORMUTH, J.H. \& ROPER, C.F.E. 1983. Quantitative sampling of oceanic cephalopods by nets: problems and tecommendations. Biological Oceanography, 2, 357-377. 